Article

\title{
Mapping the Publishing Challenges for an Open Access University Press
}

\author{
Megan Taylor $\mathbb{D}$ \\ Computing and Library Services, University of Huddersfield Press, Huddersfield HD1 3DH, UK; \\ m.taylor2@hud.ac.uk
}

Received: 13 September 2019; Accepted: 6 November 2019; Published: 11 November 2019

\begin{abstract}
Managing a New University Press (NUP) is often a one-person operation and, with limits on time and resources, efficiency and effectiveness are key to having a successful production process and providing a high level of author, editor and reader services. This article looks at the challenges faced by open access (OA) university presses throughout the publishing journey and considers ways in which these challenges can be addressed. In particular, the article focuses on six key stages throughout the lifecycle of an open access publication: commissioning; review; production; discoverability; marketing; analytics. Approached from the point of view of the University of Huddersfield Press, this article also draws on discussions and experiences of other NUPs from community-led forums and events. By highlighting the issues faced, and the potential solutions to them, this research recognises the need for a tailored and formalised production workflow within NUPs and also provides guidance how to begin implementing possible solutions.
\end{abstract}

Keywords: publishing; research; higher education; education; social sciences; open access; monographs; publishing process; REF2021

\section{Introduction}

In recent years there has been a significant rise in the number of New University Presses (NUPs) in the UK. NUPs have been defined as those presses to launch from 2015 onwards, after a stable period with little change between 1980 and 2015 [1]. At the latest count there are at least 21 NUPs now active in the UK [2]. The vast majority of these publish open access (OA) journals and monographs, with some producing print products alongside [1]. The University of Huddersfield Press (the Press) is counted among these 21 NUPs, and currently publishes 10 OA academic journals and has a growing open access monographs program.

Currently in its 12th year of operation, the Press has grown to become an open access publisher of high-quality research across a broad range of subject areas including Music, History, Art, Theatre, Pharmacy, Education, Politics and Literature. The Press is particularly keen to support emerging researchers and foster research communities by providing a platform for developing or niche academic areas. Student research is also actively supported through the pioneering Fields journal [3]. The Press published all work under a Creative Commons license, and whilst it does charge a Book Processing Charge (BPC) to cover production costs, there are no Article Processing Charges (APC) for journal articles.

The management structure of The Press was overhauled in 2016 when, for the first time, a permanent Press Manager was appointed. This provided the resource and opportunity for a full audit of Press activity, with the aim of implementing and improving processes across the board in order to deliver a professional publishing service and allow planning for expansion. Even with this new investment in staffing, it brings the staff total for the Press to 0.6 full time equivalent (FTE), significantly below the UK average of 1 FTE [4]. This low level of staff resource, plus an often unpredictable organic growth rate [5], means that all changes to the Press service and procedures need to be carefully mapped and 
approached systematically. This paper lays out the six key areas which the Press has focused on since 2016 in order to enable a professional, efficient and effective publishing process that suits our journal and monograph portfolio:

- Commissioning;

- Review;

- Production;

- Discoverability;

- Marketing;

- Analytics.

\section{Commissioning}

A well thought out commissioning plan for books and journals is key if publishing activities are going to be strategic and targeted, rather than reactive. Naturally, the Press receives a certain level of journal and book proposals organically when academic staff decide to approach the Press to explore the concept of a new journal or book, often following a recommendation from a colleague. There has been an increase in the number of these proposals over the last three years due to an increasing awareness of the Press across the University. Part of the role of the Press is to react to these proposals, guide them through the proposal and review process and work closely with the authors and editors to produce a publication which is well researched, meaningful and demonstrates impact. The Press also proactively identifies opportunities for new journals and books in line with the key areas identified by the University of Huddersfield Research Strategy [6].

The Research Strategy focuses on four key approaches when considering research activity:

- Excellence with impact;

- Investing in people;

- Research environment;

- 'Facing outwards' (international).

Moving to an open access publishing model has helped us to address each of the above aims:

- Making our work accessible to those in policy, practice and industry encourages real world impact.

- Providing a professional publishing platform and service to our authors, editors and readers is an investment in the researchers we work with.

- Publishing our research open access gives us the opportunity to create an inclusive research environment open to early career researchers (ECRs), students and practitioners.

- Focusing on 'facing outwards' encourages an international approach to recruiting editorial board members, editors and co-authors as well as a commitment to contributing to the wider university press community [7].

However, for commissioning purposes, the Press needs to drill down further and look at individual subject areas to identify publication opportunities. The current Press model for this mapping activity uses the Research Excellence Framework (REF2021, method of assessing research and awarding funding in the UK) units of assessment (UoAs) [8], as this framework is how research activities are being mapped across the University. In Table 1 the Panel column refers to the assessment panels, which are organized to include the REF2021 UoAs.

This mapping exercise was useful in two key ways: it confirmed the 'hunch' that the Press has historically specialised in music, art and history titles, and, perhaps more interestingly, showed that the newest titles and forthcoming ones are really helping the Press to make inroads into subject areas previously unexplored. By using this map, we can identify key areas for growth for monographs - potentially panels C and D. Two archived journals, RADAR and Mental Health and 
Learning Disabilities Research and Practice (MHLDRP), have been excluded from the above mapping exercise as they no longer publish new work, and the Fields Journal has also been left out as it is a student journal covering all seven schools and is therefore difficult to accurately map to the UoAs. The Press is in the process of expanding this exercise to compare it to a range of other NUPs.

Table 1. Publications grouped by unit of assessment.

\begin{tabular}{|c|c|c|c|c|}
\hline Panel & UoA No. & UoA Title & Journals & Books \\
\hline \multirow{6}{*}{ A } & 1 & Clinical Medicine & & \\
\hline & 2 & $\begin{array}{l}\text { Public Health, Health Services } \\
\text { and Primary Care }\end{array}$ & & \\
\hline & 3 & $\begin{array}{c}\text { Allied Health Professions, } \\
\text { Dentistry, Nursing and Pharmacy }\end{array}$ & $\begin{array}{l}\text { British Journal of } \\
\text { Pharmacy }\end{array}$ & \\
\hline & 4 & $\begin{array}{l}\text { Psychology, Psychiatry and } \\
\text { Neuroscience }\end{array}$ & $\begin{array}{l}\text { Crime, Security and } \\
\text { Society }\end{array}$ & \\
\hline & 5 & Biological Sciences & $\begin{array}{l}\text { Crime, Security and } \\
\text { Society }\end{array}$ & \\
\hline & 6 & $\begin{array}{l}\text { Agriculture, Veterinary and Food } \\
\text { Science }\end{array}$ & & \\
\hline \multirow{6}{*}{ B } & 7 & $\begin{array}{l}\text { Earth Systems and Environmental } \\
\text { Sciences }\end{array}$ & & \\
\hline & 8 & Chemistry & $\begin{array}{c}\text { Advances in Chemical } \\
\text { Engineering, Student } \\
\text { Perspectives }\end{array}$ & \\
\hline & 9 & Physics & & \\
\hline & 10 & Mathematical Sciences & & \\
\hline & 11 & Computer Science and Informatics & & \\
\hline & 12 & Engineering & $\begin{array}{c}\text { Advances in Chemical } \\
\text { Engineering, Student } \\
\text { Perspectives }\end{array}$ & \\
\hline \multirow{11}{*}{$\mathrm{C}$} & 13 & $\begin{array}{l}\text { Architecture, Built Environment } \\
\text { and Planning }\end{array}$ & $\begin{array}{l}\text { Crime, Security and } \\
\text { Society }\end{array}$ & \\
\hline & 14 & $\begin{array}{c}\text { Geography and Environmental } \\
\text { Studies }\end{array}$ & & \\
\hline & 15 & Archaeology & $\begin{array}{c}\text { Postgraduate } \\
\text { Perspectives on the Past }\end{array}$ & \\
\hline & 16 & Economics and Econometrics & & \\
\hline & 17 & $\begin{array}{l}\text { Business and Management } \\
\text { Studies }\end{array}$ & & \\
\hline & 18 & Law & & \\
\hline & 19 & Politics and International Studies & Identity Papers & \\
\hline & 20 & Social Work and Social Policy & Identity Papers, CSS & \\
\hline & 21 & Sociology & Identity Papers & \\
\hline & 22 & $\begin{array}{l}\text { Anthropology and Development } \\
\text { Studies }\end{array}$ & & \\
\hline & 23 & Education & TiLL & \\
\hline
\end{tabular}


Table 1. Cont.

\begin{tabular}{|c|c|c|c|c|}
\hline Panel & UoA No. & UoA Title & Journals & Books \\
\hline \multirow{11}{*}{$\mathrm{D}$} & 24 & $\begin{array}{l}\text { Sport and Exercise Sciences, } \\
\text { Leisure and Tourism }\end{array}$ & & \\
\hline & 25 & Area Studies & & \\
\hline & 26 & $\begin{array}{l}\text { Modern Languages and } \\
\text { Linguistics }\end{array}$ & Identity Papers & \\
\hline & 27 & English Language and Literature & & Grist \\
\hline & 28 & History & $\begin{array}{c}\text { Postgraduate } \\
\text { Perspectives on the Past }\end{array}$ & $\begin{array}{c}\text { Beerhouses, } \\
\text { Ramsden Estate }\end{array}$ \\
\hline & 29 & Classics & & \\
\hline & 30 & Philosophy & & \\
\hline & 31 & Theology and Religious Studies & Identity Papers & \\
\hline & 32 & $\begin{array}{l}\text { Art and Design: History, Practice } \\
\text { and Theory }\end{array}$ & & \\
\hline & 33 & $\begin{array}{l}\text { Music, Drama, Dance, Performing } \\
\text { Arts, Film and Screen Studies }\end{array}$ & $\begin{array}{c}\text { Divergence Press, } \\
\text { Journal of Creative } \\
\text { Music Systems, Journal } \\
\text { of Performance Magic, } \\
\text { Performance and } \\
\text { Mindfulness }\end{array}$ & $\begin{array}{l}\text { Soundings, Music } \\
\text { Beyond Airports, } \\
\text { Shibusa, Noise, } \\
\text { Overcoming Form }\end{array}$ \\
\hline & 34 & $\begin{array}{l}\text { Communication, Cultural and } \\
\text { Media Studies, Library and } \\
\text { Information Management }\end{array}$ & & Soundings \\
\hline
\end{tabular}

Whilst this subject map can certainly help the Press identify areas of strength to continue with, and new areas for growth, for this to be carried out successfully it needs to be considered alongside the capacity of the publication process. It is no use starting aggressive expansion programmes when there are no resources or processes in place to deliver these publications to the high standards which the Press is proud to maintain. For this reason, the first step towards a strategic commissioning process needed to be an audit and development of the publishing processes, which is explored in Section 4 .

\section{Review}

The Press operates a double blind peer review system as standard for OA journals, and the review process for monographs is just as rigorous, if slightly different. Monograph proposals are reviewed by the Press Board, and, if accepted, sample chapters are then reviewed by both the Editor of the book (if an edited collection) and at least two reviewers in the field. Whilst the Press does not carry out any of the reviews centrally, it is still responsible for making sure the review process is understood by the journal and monograph editors, and that it is communicated clearly to authors and readers. The Press follows the guidelines set out by the Committee for Publication Ethics (COPE) [9].

Transparency is particularly important for OA publications as, with the unfortunate rise of predatory OA journals [10], it is paramount that ethical, professional high quality OA publications can stand apart and be recognised as academic publications of high standards and professional quality. The Press has worked to improve transparency of our processes by including statements about the review process, business model and copyright procedure on the main Press website in addition to the individual journal pages. With the move to a new publishing platform in 2018 (Janeway, built and serviced by the Open Library for Humanities), the Press built in even more detailed information on these areas to the new platform. The merging of the Press website and journal pages onto one platform allows for higher levels of consistency in information. Some of the individual Press titles are approved by the Committee for Publication Ethics (COPE), and a full application for Publisher member status 
has been submitted and is currently undergoing the review process. It is important that the Press works towards this full membership to demonstrate the understanding and commitment we have to ethical publication practices.

The new platform also gives the Press the opportunity to have, for the first time, a high quality, tailored submission system. There are three levels of dashboards for authors, editors and the Press Manager, allowing each stakeholder to monitor the progress of an article (author), issue (Editor) or journal (Press Manager). This move from an email-based system to a web-based system means that authors can enjoy the transparency of the review process and understand where their paper is in the system. At the same time, the new system improves efficiency for the editors, resulting in less time-consuming admin tasks, and also allows the Press Manager a more accessible overview of all items in the review process to allow for more effective issue scheduling as part of the annual publication schedule.

Whilst having access to the submission system undoubtedly improves workflows and transparency, it is the Press relationships with the editors which act as the building blocks for this. Developing and maintaining mutually productive and supportive relationships between publisher and editor is key to achieving an efficient and transparent workflow. Regular catch ups with editors, plus the development of improved resources [11], are all contributing to a smoother production process and an improved level of service for authors.

\section{Production}

As the Press has developed organically, and in accordance with limited resources, the production workflow that was fit for purpose when the Press launched became unsuitable following expansion and the growing need for more detailed analytics around usage and dissemination. This requirement for change was identified during the Press Manager audit in 2016 and has been addressed with the move to a new publication platform, Janeway, in November 2018. The main deciding factor for choosing Janeway was the integration, throughout the platform, of a diverse range of tools and services specifically tailored to OA publishing processes. The Press is dedicated to OA publishing across the portfolio, and it was important that we found a platform that could mirror this and provide all the options we needed to improve our OA products.

Whilst the overhaul of the production process addresses issues of capacity and workflow, it is also being made in response to current developments across the wider higher education and research environment. Taylor and Jensen outlined in a previous paper that researchers are:

'under increasing pressure to demonstrate research impact, not just in terms of scholarly impact but also impact on communities and end users, the need for improved analysis and reporting is continually growing. This increase in demand for demonstration of research impact and environment highlights the importance of properly funded and resourced support within the Library to deliver this across universities and ensure academic staff are well prepared and supported in these needs' [11].

As explored in an earlier publication by Taylor and Jensen [11], the Press has been working to pre-empt the need for increased levels of impact and analysis data for the next Research Excellence Framework (REF) by looking at how the Press publishing process can be further improved to provide the required data alongside a streamlined and tailored author and editor experience. Before approaching the market to identify potential solutions it was important to map out the requirements of the Press in detail. Table 2 shows the basic requirements for an optimised production workflow: 
Table 2. Platform requirements.

\begin{tabular}{ll}
\hline Journals & Full Publication Platform from Submission to Dissemination \\
\hline & Pre-production checklist \\
Integrated copyediting stage & COUNTER compliant \\
& Crossref compatible \\
& ORCID integration \\
& Proof stage \\
& Detailed analytics \\
& Admin dashboard \\
& Annual schedule \\
& Preservation integration \\
& Hosted books pages \\
Chapter level metadata \\
Mooks \\
Multiple format options \\
Print sales links \\
Detailed analytics
\end{tabular}

Once these requirements were mapped out the Press then approached the market and looked at a range of solutions, from free open source software right up to fully managed publishing packages from third parties. The outcome was that Janeway was the platform that could address all of the requirements, plus offer more than we had anticipated, within a manageable budget. Features which particularly appealed to us included the automatic registration of digital object identifiers (DOIs), the ability to send content to a preservation service at the click of a button, and the wide range of analytics available at Press and title level. The Press was the first publisher to sign with Janeway [12], and the move was completed in November 2018.

\section{Discoverability}

At a Jisc-organised OA community workshop in 2017 [13], there was a discussion group on discoverability, and it was, unsurprisingly, one of the busiest tables in the room (apart from the REF table). Jisc have done a lot of work around the discoverability of OA research, and have provided a regularly updated guide on OA impact and usage:

'To ensure the full benefits of open access (OA) research are realised, it must be made easy to find and use. But simply placing research outputs in an institutional repository is not enough. You can take steps to raise the visibility of your institution's repository and help ensure users can find and use relevant content. Measuring the reach of research is a valuable way for institutions to demonstrate impact, as required for example for the research excellence framework (REF). Being able to track and benchmark usage can help identify trends within your own repository and your research, and compare performance with other institutions' [14].

This is useful, but how do university presses who do not use their repository to publish address issues of discoverability? Additionally, what about all the third party services out there which can help with visibility for journals and monographs? The landscape of aggregators, registers and repositories is constantly shifting, and it can be hard to navigate. The Press has tried to approach this issue systematically and started by collecting details of all the potential channels for increasing discoverability, which can be seen in Table 3. So far, the Press has been successful in having journals accepted to DOAJ [15], Scopus, Science Open [16] and Portico, and books to OAPEN, DOAB and Muse. 
Table 3. Third party platforms.

\begin{tabular}{ll}
\hline Journals & JSTOR-Digital Library of Academic Journals, Books, and Primary Sources. \\
\hline DOAJ—the Directory of Open Access Journals \\
\hline Portico-content preservation service \\
\hline Semantic Scholar-search engine for academic research \\
\hline PubMed Central—archive of life sciences published work \\
\hline OAJSE-Open Access Journals Search Engine \\
\hline Scopus—indexing and ranking of published work \\
\hline Science Open—content hosting service \\
\hline OAPEN-OA academic books platform \\
\hline Muse-digital humanities and social science content, hosted \\
\hline DOAB-Directory of Open Access Books
\end{tabular}

In addition to these services there are also subject specific services and repositories, plus internal platforms to consider (for Huddersfield this is Summon, the library search engine used by students and staff), and the standard methods of improving discoverability through website structure, coding and metadata in order to appear in search engines such as Google Scholar. An internal project the Press is currently working on is looking at the potential for highlighting appropriate journals or monographs in module or course handbooks, particularly in the case of our student research journal Fields.

Resource and funding are bound to impact on which discoverability services a press chooses to opt for, but whichever ones are used it is crucial to monitor how effective they are in terms of readership. Studies indicate that increased readership will usually translate into increased citations [17-20], so if increasing the usability and impact of your OA research is your goal, then making it more visible and accessible is a major first step. Most of the services identified in Table 3 can offer statistics reports which can be compared against a publication's overall statistics for an understanding of how much traffic is coming from external/internal sources.

\section{Marketing}

Following on from discoverability, once you have made your content available and accessible to a wide audience, how do you go about marketing it? Marketing of OA publications is by nature different to the marketing of traditional print-only or subscription publications. With print or subscription publications the marketing task is essentially to sell something based on a snapshot or summary of the contents, whereas with OA content you want to encourage readership of it, but can utilise all of the content, and market to any appropriate audience, as there are no restrictions on access.

In discussions with potential and past authors, the Press has received a number of queries around the effect of OA on readership, both in terms of downloads and print sales. Authors often expect that, when they publish a monograph both OA and in print, the print sales will be very low as everyone will opt for the free online version. Conversely, the Press has found that print monograph sales have increased throughout our OA monograph programme, as with the combination of an OA version and a print version, the Press can more effectively market the titles and improve discoverability. This is in line with the findings from the OAPEN report on the impact of OA publishing on monographs, which also reported no negative impact on print sales, and increased level of discoverability [21]. The visibility of Press monographs has increased following participation in services such as DOAB and OAPEN, resulting in readership in the form of OA downloads, but also increased sales of the print version.

In terms of journals, there is no doubt that we reach a much wider audience with our OA journals than we would with a subscription model which would only be accessed by a selection of institutions through the agreed deals they have with their content providers [22]. Making our content OA means 
that Press marketing activities can encompass the public, professional, government and NGO sectors in addition to traditional scholarly audiences.

The majority of these marketing activities take place via the Press social media channels, which have grown to include Twitter, Facebook, the Press blog and we are soon to add Instagram to this list. The Press uses Agora Pulse, a social media management platform, to monitor our social media marketing, and the reporting system has enabled us to extract useful analysis of past activities to inform strategic planning of future activities.

Figures 1 and 2 show some of the useful statistical analysis we can now do using our social media management platform. The simple report in Figure 1 allows us to see how our audience, level of content and level of engagement have all grown in 2019. In Figure 2 we can see spikes of engagement over the weeks and months, which is really useful for figuring out the types of messages which our community find most useful. In 2019 we have found that the most popular posts have been those discussing new releases, and links to our blog posts.

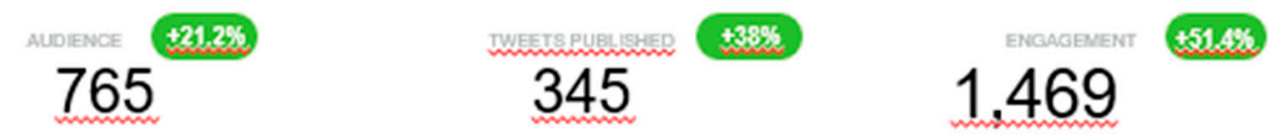

Figure 1. Key stats exported from AgoraPulse January-September 2019.

\section{Engagement}

Likes, replies, messages and retweets on your tweets:

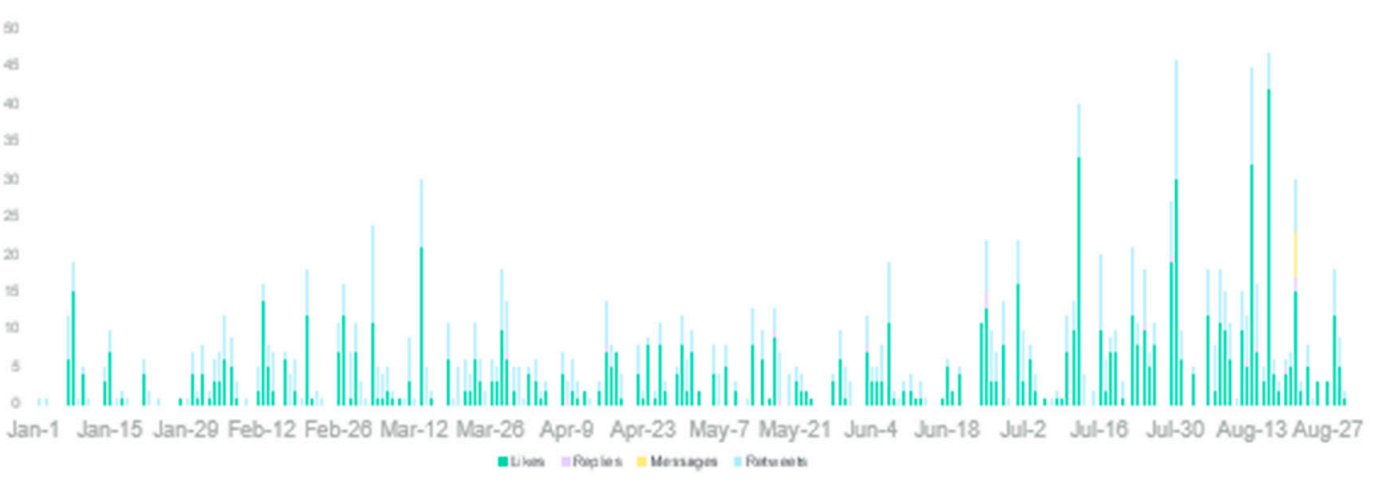

Likes

Replies

Messages

Retweets

Total Engagement

Figure 2. Graph indicating engagement levels exported from AgoraPulse January-September 2019.

\section{Analytics}

It is clear from the Marketing section that finding useful analytics to monitor can aid forward planning and enable more strategic decisions to be made around future activities and campaigns. Alongside altmetrics analytics, the Press also monitors downloads of books and journals to track the readership of open access publications over time. Following the move to the Janeway platform in October 2018, the Press now has access to enhanced analytics which allows comparisons over an extended time period. 
Collecting and monitoring the download statistics (Table 4) has enabled the Press to look at how widely read the open access titles are, and monitor fluctuations in readership over time. Figure 3 shows the download statistics for journals over a 2 year period, from 2017 up to July 2019.

Table 4. Annual downloads.

\begin{tabular}{cc}
\hline Year & All Press Article Downloads \\
\hline 2016 & 28,419 \\
\hline 2017 & 35,075 \\
\hline 2018 & 46,074 \\
\hline 2019 (January-August) & 38,972 \\
\hline
\end{tabular}

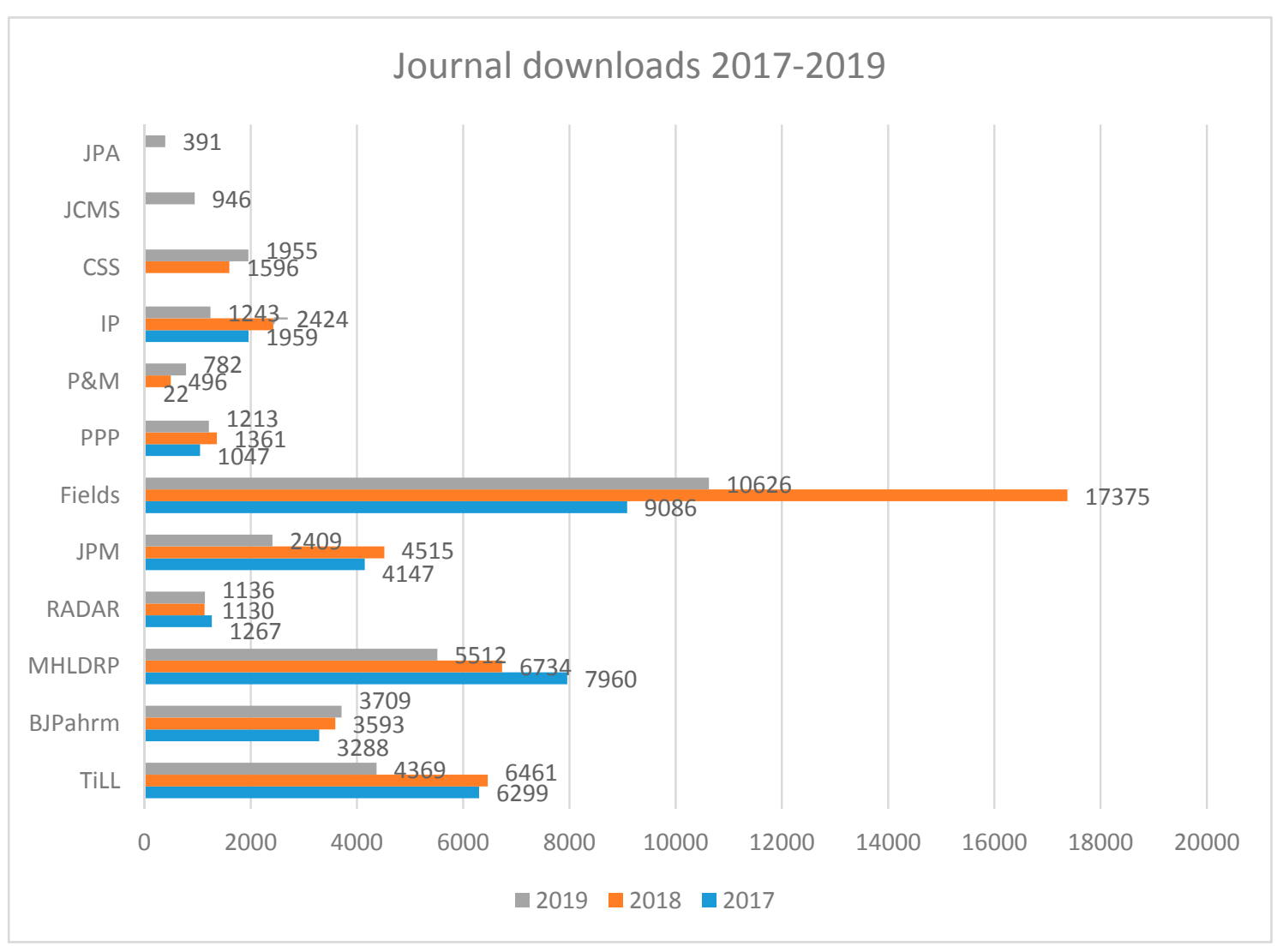

Figure 3. Journal download figures for 2017-2019, including JPA-Journal of Play in Adulthood; JCMS-Journal of Creative Music Systems; CSS - Crime, Security and Society; IP_Identity Papers; P\&M-Performance and Mindfulness; PPP—Postgraduate Perspectives on the Past; Fields— Fields: Journal of Huddersfield Student Research; JPM—Journal of Performance Magic; RADAR; MHLDRP_ Mental Health and Learning Disabilities Research and Practice; BJPharm—British Journal of Pharmacy; TiLL-Teaching in Lifelong Learning.

We increased our article downloads by $31 \%$ over 2018, and we are on target to further increase this figure by the end of 2019. The student journal Fields is responsible for a significant share of the overall Press journal downloads-an encouraging result for a pioneering student journal. It is also clear from this graph that MHLDRP has significant readership, despite the fact it ceased publication in 2011. This indicates that the research published in this open access journal remains relevant to the community and has longevity. This has prompted the Press to enter discussions with researchers about the possibility of relaunching the journal to once again provide a space for this much used field of research. 
We have applied the same level of statistical usage analysis to our OA monographs, and the results have been used to evaluate our trials with selected third party discoverability services. In Figure 4 we can see that usage of OA monographs in 2019 has increased by 30\% up to 7893 downloads in just January-July, thanks to a combination of tailored marketing plans for each title, and increased visibility via the platforms mentioned in Section 4.

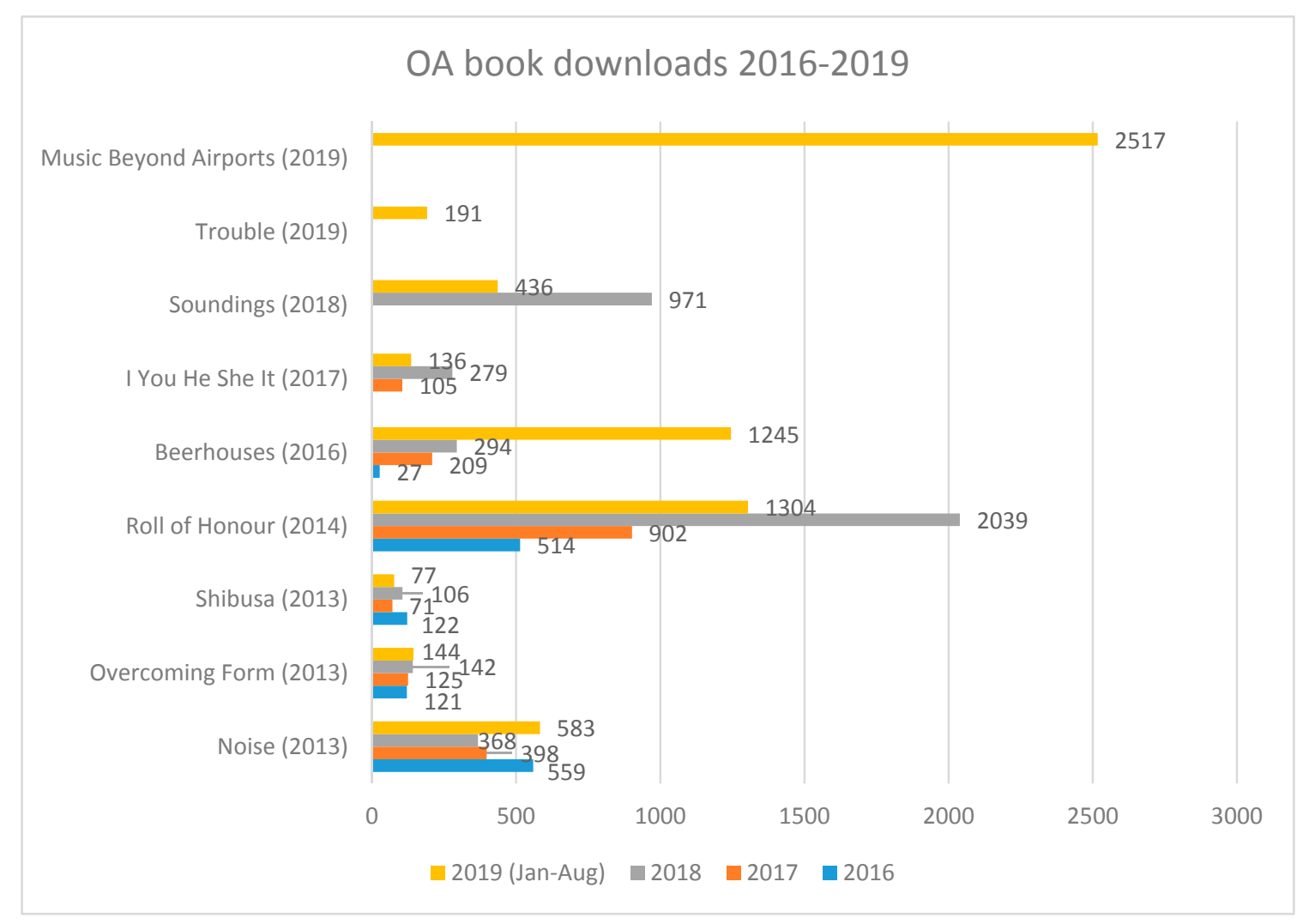

Figure 4. OA book downloads 2016-2019

It is clear that overall readership is on the increase for the Press, and we expect this trend to continue as we work to further increase discoverability and reader, author and editor experience. However, it would be more useful to see if this increased readership is also leading to increased impact in terms of citations to the publications. Currently, the only way the Press can monitor citations is manually via Google Scholar, meaning that the data we have is limited, time consuming to collate and not fully comprehensive. Janeway are currently working on a project to integrate the platform with Crossref cited-by [23], which will give the Press access to full citation data for all titles, making this analysis accurate and feasible for the first time.

\section{Conclusions}

The Press is confident that the recent and future changes to the publishing processes and platforms used will be fit for purpose and yield positive results including a streamlined workflow, increased discoverability, an improved level of service for authors and editors, an improved reader experience, and ultimately, a steady and measurable increase in downloads and citations.

The Press is already seeing the benefits of optimising publishing processes with significant increases in OA readership, particularly in 2018 and 2019. That said, there is a lot of work to be done around the analytics and how they are interpreted and acted upon. There has been a significant shift in the amount of data the Press has access to about overall and title-specific readership, and it is crucial 
that this data is maintained, monitored and interpreted in ways which can prove useful for strategic decision making, particularly when it comes to commissioning and expansion plans.

A significant amount of the work involved in the platform move to Janeway focused on journal content, but we were keen to not overlook the importance of our monograph programme. It is important that the open access monograph programme is optimised and monitored, particularly in light of the OA monograph requirements for REF2027 [24]. The initial steps to achieve this have been taken, with an improved distributor agreement and improved discoverability via Janeway, Muse, Science Open, DOAJ, DOAB and OAPEN.

\section{Limitations}

The Press has made significant improvements to the quality of service and resources available to the research community, as well as improved content discoverability and usage. However, there is a lot more to be done in terms of optimising the OA content further, including issues such as chapter level DOIs, extending the range of formats and looking at XML versions for a seamless online readership experience. Currently, all this work comes at a cost which can be prohibitive for small university presses, and not-for-profit presses. Nevertheless, the Press is exploring the ever-changing digital services offered by an increasing number of service providers, and is working towards full-text publication, alongside the current download options, for OA books and journals.

The Press has taken steps to map out the key sections discussed in this paper, incorporating them into a proposed Press Model for university presses. This was developed out of our own research and experiences, but also out of a community event organized at Huddersfield in June 2018. The Model was published in UKSG Insights [7] and is still open for comment and input from those in the scholarly communications community.

Funding: This research received no external funding.

Conflicts of Interest: The authors declare no conflict of interest.

\section{References}

1. Lockett, A.; Speicher, L. New university presses in the UK: Accessing a mission. Learn. Publ. 2016, 29, 320-329. [CrossRef]

2. Blanchett, H. Open access briefing: OA monographs in the UK. 2018. Available online: https: //scholarlycommunications.jiscinvolve.org/wp/2018/10/25/open-access-briefing-oa-monographs-in-the-uk/ (accessed on 13 September 2019).

3. Stone, G.; Jensen, K.; Beech, M. Publishing Undergraduate Research: Linking Teaching and Research through a Dedicated Peer-Reviewed Open Access Journal. J. Sch. Publ. 2016, 47, 147-170. [CrossRef]

4. Adema, J.; Stone, G. Changing Publishing Ecologies-A Landscape Study of New University Presses and Academic-Led Publishing. 2017. Available online: https://repository.jisc.ac.uk/6666/1/Changing-publishingecologies-report.pdf. (accessed on 13 September 2019).

5. Developing a Sustainable Publishing Model for a University Press: A Case Study of the University of Huddersfield. 2011-2015 University of Huddersfield Repository. Available online: http://eprints.hud.ac.uk/ id/eprint/33791/ (accessed on 13 September 2019).

6. Research Strategy and Governance. Available online: https://research.hud.ac.uk/strategy/ (accessed on 13 September 2019).

7. Taylor, M.; Jensen, K.S.H. Developing a model for university presses. UKSG Insights 2019, 32. [CrossRef]

8. England, H.F.C. Units of Assessment-REF 2021. Available online: https://www.ref.ac.uk/panels/units-ofassessment/. (accessed on 13 September 2019).

9. Committee on Publication Ethics: COPE. Available online: https://publicationethics.org/guidance/Guidelines (accessed on 13 September 2019).

10. Laine, C.; Winker, M.A. Identifying predatory or pseudo-journals. Biochem. Medica 2017, 27, 285-291. [CrossRef] [PubMed] 
11. Taylor, M.; Jensen, K.S.H. Engaging and Supporting a University Press Scholarly Community. Publications 2018, 6, 13. [CrossRef]

12. University of Huddersfield Press Becomes First to Use Hosted Janeway Service for Journals. Available online: https://www.openlibhums.org/news/274/ (accessed on 13 September 2019).

13. Open Access Community Workshop Jisc. Available online: https://www.jisc.ac.uk/events/open-accesscommunity-workshop-05-dec-2017 (accessed on 13 September 2019).

14. Open Access: Discovery, Usage and Impact. Available online: https://www.jisc.ac.uk/guides/open-accessdiscovery-usage-and-impact (accessed on 13 September 2019).

15. New Journals Accepted into the Directory of Open Access Journals (DOAJ); University of Huddersfield Press: Huddersfield, UK, 2019.

16. ScienceOpen, November 18th 2018. Available online: https://blog.scienceopen.com/tag/university-ofhuddersfield-press/ (accessed on 13 September 2019).

17. Li, Y.; Wu, C.; Yan, E.; Li, K. Will open access increase journal CiteScores? An empirical investigation over multiple disciplines. PLoS ONE 2018, 13, e0201885. [CrossRef] [PubMed]

18. Björk, B.C.; Solomon, D. Open access versus subscription journals: A comparison of scientific impact. BMC Med. 2012, 10, 73. [CrossRef] [PubMed]

19. Melissa Terras' Blog: Is Blogging and Tweeting about Research Papers Worth It? The Verdict. Available online: http://melissaterras.blogspot.com/2012/04/is-blogging-and-tweeting-about-research.html (accessed on 13 September 2019).

20. Open Access Meets Discoverability: Citations to Articles Posted to Academia.edu. Available online: https://journals.plos.org/plosone/article?id=10.1371/journal.pone.0148257 (accessed on 13 September 2019).

21. OAPEN-CH-The Impact of Open Access on Scientific Monographs in Switzerland-SNF. Available online: http://www.snf.ch/en/funding/science-communication/oapen-ch/Pages/default.aspx. (accessed on 10 October 2019).

22. Schonfeld, Roger Is the Value of the Big Deal in Decline? Available online: https://scholarlykitchen.sspnet. org/2019/03/07/value-big-deal-leakage/ (accessed on 10 October 2019).

23. Cited-by-Crossref. Available online: https://www.crossref.org/services/cited-by/ (accessed on 13 September 2019).

24. [ARCHIVED CONTENT] HEFCE Blog. Available online: https://webarchive.nationalarchives.gov.uk/ 20180801134745/https://blog.hefce.ac.uk/ (accessed on 13 September 2019).

(C) 2019 by the author. Licensee MDPI, Basel, Switzerland. This article is an open access article distributed under the terms and conditions of the Creative Commons Attribution (CC BY) license (http://creativecommons.org/licenses/by/4.0/). 